\title{
Workshop Penerapan Software GeoGebra Sebagai Media Pembelajaran Matematika Untuk Guru Sekolah Dasar Kelurahan Pademangan Barat
}

\author{
Rizki Dwi Siswanto ${ }^{1}$, Ervin Azhar ${ }^{2}$ \\ ${ }^{1,2}$ Prodi Pendidikan Matematika, FKIP, UHAMKA \\ 1rizkidwisiswanto@uhamka.ac.id
}

\begin{abstract}
ABSTRAK
Kegiatan pengabdian ini dilatarbelakangi oleh permasalahan mitra yang diidentifikasi (1) belum memiliki pengetahuan tentang media pembelajaran terutama GeoGebra sehingga perlu adanya pendampingan dan pengarahan berkelanjutan mengenai pentingnya menggunakan media pembelajaran yang tepat ketika proses pembelajaran, (2) belum memiliki keterampilan GeoGebra sehingga perlu diadakan kegiatan pelatihan penggunaan software GeGebra. Permasalahan pada mitra di daerah Kelurahan Pademangan Barat dapat dicari solusinya, salah satunya dengan penerapan IPTEKS bagi masyarakat sekitar khususnya untuk guru dan siswa. Solusi yang ditawarkan guna memecahkan masalah di atas adalah tim pengabdian UHAMKA bermaksud mengadakan workshop penerapan software GeoGebra sebagai media pembelajaran matematika untuk guru SDN Pademangan Barat. Metode dalam menyelesaikan permasalahan yang dihadapi oleh mitra yaitu (1) penggalian masalah, (2) perencanaan, (3) sosialisasi, (4) pelaksanaan, (5) evaluasi dan refleksi, (6) laporan, dan (7) publikasi. Hasil pelaksanaan pengabdian berupa (1) publikasi artikel ilmiah, (2) buku panduan software GeoGebra, dan (3) teratasinya masalah mitra
\end{abstract}

Kata kunci: Workshop, Software GeoGebra, Media Pembelajaran

\section{PENDAHULUAN}

Tantangan masa depan yang selalu berubah sekaligus persaingan yang semakin ketat memerlukan lulusan pendidikan yang tidak hanya terampil dalam satu bidang, tetapi juga kritis dan kreatif dalam mengembangkan bidang yang ditekuni. Hal ini perlu diterapkan dalam setiap satuan pendidikan, terutama sekolah. Oleh karena itu, dalam standar kompetensi lulusan Kurikulum 2013 menyatakan bahwa siswa diharapkan memiliki kompetensi yang terdiri dari aspek kompetensi sikap, pengetahuan, dan keterampilan (Depdikbud, 2013). Kompetensi yang dimaksudkan telah dijelaskan dalam standar isi untuk satuan pendidikan dasar dan menengah, bahwa mata pelajaran matematika perlu diberikan kepada semua perserta didik mulai dari sekolah dasar untuk membekali peserta didik dengan kemampuan berpikir logis, analitis, sistematis, kritis, dan kreatif, serta kemampuan bekerjasama (Depdiknas, 2006). Sehingga konten kurikulum harus selalu mengikuti perkembangan ilmu pengetahuan, budaya, teknologi, dan seni, membangun rasa ingin tahu dan kemampuan bagi peserta didik untuk mengikuti dan memanfaatkan secara tepat hasil-hasil ilmu pengetahuan, teknologi, dan seni.
Berdasarkan hal tersebut tentu saja sekolah, terutama guru sering dianggap menjadi instrument utama tolok ukur terlaksananya tujuan pembelajaran yang diharapkan. Sehingga, kompetensi guru seringkali diuji agar jalannya proses pembelajaran memberikan dampak yang baik terhadap hasi belajar siswa. Proses pembelajaran yang dilakukan oleh guru dan siswa di kelas dari waktu ke waktu menjadi tolok ukur penentu keberhasilan pembelajaran karena akan berdampak pada berbagai hal yang lain seperti dikatakan oleh Slameto (2003) bahwa belajar ialah suatu proses usaha yang dilakukan seseorang untuk memperoleh suatu perubahan tingkah laku yang baru, secara keseluruhan sebagai hasil pengalamannya sendiri dalam interaksi dengan lingkungannya. Jadi, dapat dikatakan bahwa melalui usaha yang dilakukan guru, tingkah laku siswa dapat berubah ke arah positif.

Namun, fakta yang terjadi adalah guru tidak memiliki kompetensi dalam menggunakan media pembelajaran yang kekinian atau dengan kata lain guru tidak mengedepankan IPTEK sehingga proses pembelajaran yang berlangsung selalu terkesan konvensional. Sangat disayangkan jika anakanak usia sekolah harus dibiarkan tanpa 
kegiatan yang mengandung kemajuan IPTEK. Padahal Djamarah dan Zain (2006) menjelaskan bahwa belajar adalah proses perubahan prilaku berkat pengalaman dan latihan. Perkembangan teknologi komputer yang pesat memberikan peluang luas kepada kita untuk memanfaatkannya dalam berbagai hal, termasuk untuk meningkatkan efektivitas pembelajaran. Berbagai manfaat program komputer dalam pembelajaran matematika dikemukakan oleh Kusumah (2003). Menurutnya, program-program komputer sangat ideal untuk dimanfaatkan dalam pembelajaran konsep-konsep matematika yang menuntut ketelitian tinggi, konsep atau prinsip yang repetitif, penyelesaian grafik secara tepat, cepat, dan akurat. Lebih lanjut Kusumah (2003) juga mengemukakan bahwa inovasi pembelajaran dengan bantuan komputer sangat baik untuk diintegrasikan dalam pembelajaran konsep-konsep matematika, terutama yang menyangkut transformasi geometri, kalkulus, statistika, dan grafik fungsi. Menurut Ariani Niken (dalam Rifayanti, 2017), animasi menjadi pilihan untuk menujang proses belajar yang menyenangkan dan menarik bagi siswa dan juga memperkuat motivasi, dan juga untuk menanamkan pemahaman pada siswa tentang materi yang diajarkan

Berdasarkan hasil observasi tim pada tanggal 22 Februari 2018, sekitar 40 orang guru yang bertugas di sekolah dasar Kelurahan Pademangan barat, tepatnya SDN Pademangan Barat 11 dan SDN Pademangan Barat 09 belum pernah memiliki pengalaman mengikuti pelatihan atau workshop penggunaan software GeoGebra ataupun penggunaan media pembelajaran lainnya, sehingga mereka tidak memiliki pengetahuan untuk mengaplikasikan software GeoGebra apalagi untuk menggunakan aplikasi di kelas pada proses pembelajaran. Informasi yang didapat dari kepala sekolah SDN Pademangan Barat 11 dan 09, selama ini guru-guru mengajar hanya menggunakan buku atau alat peraga seadanya yang dibeli dari dana sekolah, belum pernah ada kegiatan untuk guru maupun siswa untuk membuat alat peraganya sendiri atau menggunakan software untuk membantu pemahaman siswa terhadap pelajaran matematika. Padahal menurut Sanjaya (2009) bahwa semakin konkret siswa mempelajari bahan pelajaran, misalnya melalui pengalaman langsung, maka semakin banyaklah pengalaman yang diperoleh siswa. Jadi sangat disayangkan jika siswa-siswa sekolah dasar yang pada umumnya aktif secara psikomotorik terpasung dalam proses pembelajaran yang konvensional hanya karena keterbatasan guru dan fasilitas sekolah.

Padahal berdasarkan pegalaman tim pada dua sekolah yang akan dijadikan mitra yaitu SDN Pademangan Barat 11 dan SDN Pademangan Barat 09, sangat berpotensi untuk dilaksanakannya program PKM ini, hal tersebut berdasarkan lokasi kedua sekolah yang berdekatan sehingga mempermudah peserta untuk melaksanakan kegiatan, serta dilengkapi ruang belajar yang memadai untuk jumlah guru dan siswa yang cukup banyak ketika melaksanakan kegiatan. Selain itu, pihak sekolah pun bersedia menyiapkan sarana dan prasarana lain yang dibutuhkan tim selama kegiatan berlangsung. Dari beberapa sekolah yang ada di Kelurahan Pademangan, kegiatan ini akan berlangsung di SDN Pademangan Barat 11 dan 09 dengan jumlah peserta guru sebanyak 30-40 orang yang berasal dari berbagai sekolah sekitar, tetapi difokuskan untuk guru-guru di sekolah tersebut.

Pada kegiatan ini, tim akan menerapkan pembelajaran berbasis IPTEK, dengan menggunakan software GeoGebra. Software ini sangat familiar di jenjang universitas namun sangat awam diketahui di jenjang sekolah dasar. GeoGebra merupakan Software yang dikembangkan oleh Markus Hohenwarter pada tahun 2001. Menurut Hohenwarter (2008), GeoGebra adalah prgram komputer (software) untuk membelajarkan matematika khsusunya geometri dan aljabar. Program ini dapat dimanfaatkan untuk meningkatkan pemahaman siswa terhadap konsep yang telah dipelajari maupun sebagai sarana untuk mengenalkan atau mengkonstruksi konsep baru. Karena program komputer yang bersifat dinamis dan interaktif untuk mendukung pembelajaran dan penyelesaian persoalan matematika khususnya geometri, aljabar, dan kalkulus.

Guru akan diajarkan penggunaan software GeoGebra ini hingga mahir dan dapat diimplementasikan pada proses belajar mengajar. Software ini juga akan dibagikan kepada guru dan dipasangkan (instal) pada perangkat sekolah agar dapat bermanfaat bagi semua, terutama siswa. Software yang tim berikan sangat bermanfaat, menurut Hohenwarter (2008), program GeoGebra sangat bermanfaat bagi guru maupun siswa. Tidak sebagaimana pada penggunaan software komersial yang biasanya hanya bisa dimanfaatkan di sekolah, GeoGebra dapat diinstal pada komputer pribadi dan 
dimanfaatkan kapan dan di manapun oleh siswa. Bagi guru, GeoGebra menawarkan kesempatan yang efektif untuk mengkreasi lingkungan belajar online interaktif yang memungkinkan siswa mengeksplorasi berbagai konsep-konsep matematika. Menurut Lavicza (Hohenwarter, 2010), sejumlah penelitian menunjukkan bahwa GeoGebra dapat mendorong proses penemuan dan eksperimentasi siswa di kelas. Fitur-fitur visualisasinya dapat secara efektif membantu siswa dalam mengajukan berbagai konjektur matematis.

Menurut Hohenwarter \& Fuchs (2004), GeoGebra sangat bermanfaat sebagai media pembelajaran matematika dengan beragam aktivitas sebagai berikut.

1. Sebagai media demonstrasi dan visualisasi dalam pembelajaran yang bersifat tradisional, guru memanfaatkan GeoGebra untuk mendemonstrasikan dan memvisualisasikan konsep-konsep matematika tertentu.

2. Sebagai alat bantu konstruksi untuk memvisualisasikan konstruksi konsep matematika tertentu, misalnya mengkonstruksi lingkaran dalam maupun lingkaran luar segitiga, atau garis singgung.

3. Sebagai alat bantu proses penemuan. GeoGebra digunakan sebagai alat bantu bagi siswa untuk menemukan suatu konsep matematis, misalnya tempat kedudukan titik-titik atau karakteristik grafik parabola.

Permasalahan pada mitra di daerah Kelurahan Pademangan Barat dapat dicari solusinya, salah satunya dengan penerapan IPTEKS bagi masyarakat sekitar khususnya untuk guru dan siswa. Guru dan siswa dijadikan sasaran utama dalam kegiatan ini, karena kemajuan pendidikan di lingkungan tersebut bergantung pada dua unsur (guru dan siswa). Sementara, berdasarkan hasil diskusi dengan mitra, para guru di SDN Pademangan Barat 11 dan 09 belum memiliki kompetensi dalam menggunakan media pembelajaran yang dapat mempermudah proses pembelajaran sehingga siswa juga mudah menyerap pelajaran dengan baik. Hal ini, tentu saja saling terkait, kompetensi guru akan sangat berdampak pada hasil belajar siswa. Solusi yang ditawarkan guna memecahkan masalah di atas adalah tim pengabdian UHAMKA bermaksud mengadakan workshop penerapan software GeoGebra sebagai media pembelajaran matematika untuk guru SDN Pademangan Barat 11 dan 09.

\section{METODE KEGIATAN}

Berdasarkan solusi yang ditawarkan guna memecahkan masalah di atas adalah tim pengabdian UHAMKA bermaksud workshop penerapan software GeoGebra sebagai media pembelajaran matematika untuk guru SDN Pademangan Barat. Untuk itu, langkahlangkah yang dilakukan dalam menyelesaikan permasalahan yang dihadapi oleh kedua mitra yaitu:

1. Penggalian Masalah

Kegiatan ini diawali dengan pemberitahuan kepada pihak-pihak sekolah dan mewawancara serta pengisian instrument kepada semua unsur yang ada di sekolah, mulai dari kepala sekolah, staff, dan guru. Selain itu, tim juga mensurvei alat-alat peraga yang dimiliki sekolah tersebut. Dari hasil survei sebelum pengajuan kegiatan pelatihan para peserta memberikan sambutan dengan antusias, karena belum pernah atau sedikit sekali ada kegiatan pelatihan seperti ini. Selain itu para guru belum banyak memahami penggunaan media pembelajaran matematika yang berbasis iptek.

2. Perencanaan

Tim secara internal melakukan perencanaan untuk mendapatkan solusi terhadap masalah yang dihadapi mita, kemudian melakukan diskusi dengan mahasiswa terkait solusi yang didapat. Kemudian melakukan uji coba penggunaan Software GeoGebra dan pembuatan buku panduan Software GeoGebra. 3. Sosialisai

Setelah mendapatkan solusi, tim bersama mahasiswa melakukan sosialisai kegiatan yang akan dilakukan kepada mita serta melakukan evaluasi terhadap ide yang ditawarkan.

4. Pelaksanaan

Setelah tim dan mitra sepakat terhadap solusi yang ditawarkan, maka kegiatan pun dilaksanakan selama 3 bulan. Dengan menggunakan Software GeoGebra yang didukung oleh buku panduan yang telah disusun oleh tim.

5. Evaluasi dan Refleksi

Setelah kegiatan berlangsung, tim melakukan evaluasi kegiatan bersama mitra. Hal-hal yang dirasa kurang ketika pelaksanaan kemudian diperbaiki berdasarkan saran.

6. Laporan

Setelah kegiatan evaluasi selesai, maka laporan disusun sebagai bentuk pertanggungjawaban. 


\section{Publikasi}

Melakukan publikasi berdasarkan hasil yang didapat

\section{HASIL \& PEMBAHASAN}

Judul kegiatan ini adalah "PKM Workshop Penerapan Software GeoGebra sebagai Media Pembelajaran Matematika untuk Guru Sekolah Dasar Kelurahan Pademangan Barat" kegiatan ini digagas berdasarkan penuturan kepala sekolah dari SDN Pademangan Barat 11 yang bernama Darsini, M.Pd., beliau mentayakan selama ini guru-guru mengajar hanya menggunakan buku atau alat peraga seadanya yang dibeli dari dana sekolah, belum pernah ada kegiatan untuk guru maupun siswa untuk membuat alat peraganya sendiri atau menggunakan software untuk membantu pemahaman siswa terhadap pelajaran matematika, padahal perkembangan zaman sekarang menuntut guru dan siswa untuk lebih terampil dalam hal psikomotor dan mengikuti perkembangan zaman.

Selain itu, Ibu Darsini juga menyatakan bahwa di sana belum ada fasilitas komputer yang memadai siswa, seperti laboratorium komputer misalnya, tetapi setiap guru memiliki laptop atau notebook pribadi, sehingga dengan leluasa $\mathrm{Ibu}$ Darsini menyampaikan ingin menerima palatihan dari TIM UHAMKA mengenai pengembangan kemampuan akademik guru. Kemudian tim mengusulkan untuk mengadakan workshop penerapan software GeoGebra. Sebenarnya, kegiatan ini direncanakan di dua sekolah yaitu SDN Pademangan Barat 11 dan SDN Pademangan Barat 09, tetapi ketika mendekati pelaksanaan guru-guru di SDN Pademangan Barat 09 membatalkan diri untuk mengikuti kegiatan ini dikarenakan ada visitasi asessor untuk penilaian sekolah, sehingga kegiatan ini hanya dilaksanakan oleh guru-guru dari SDN Pademangan Barat 11. Kegiatan ini dihadiri oleh 27 guru SDN Pademangan Barat 11. Selama proses kegiatan berlangsung, peserta sangat antusias mengikuti jalannya acara, begitu banyak pertanyaan yang muncul terkait penggunaan software GeoGebra, pembicara dan tim berusaha memfasilitasinya.

Kegiatan workshop ini dilakukan selama satu hari untuk membahas materi penggunaan software GeoGebra. Workshop ini dilakukan dengan setting kegiatan yang lebih menekankan keaktifan peserta yakni melalui kegiatan inkuiri terbimbing berbantuan GeoGebra. Peserta yang merupakan guru-guru, diberikan kesempatan untuk mengeksplorasi suatu konsep atau prinsip dalam matematika melalui suatu kegiatan penyelidikan menggunakan GeoGebra. Kegiatan ini akan mendorong guru untuk dapat menggunakan pengetahuan yang telah mereka miliki sebelumnya. Selain itu, guru lebih dapat mengemukakan ide-ide serta pengetahuan matematis mereka secara terbuka untuk membangun suatu pemahaman atas konteks yang sedang dipelajari.

Secara umum pelaksanaan workshop penerapan GeoGebra ini berjalan dengan baik. Hal yang dapat tim amati selama kegiatan dilakukan adalah penggunaan software GeoGebra pada kegiatan ini merupakan hal baru bagi guru, karena itu ketika diadakan tutorial atau workshop penerapan tentang pengoperasian GeoGebra, guru terlihat sangat antusias mengikutinya dengan menggunakan laptop masing-masing. Namun beberapa guru mengaku bingung dan cukup lama dalam mengoperasikan GeoGebra. Dampaknya, setelah kegiatan selesai guru-guru mulai menggunakan GeoGebra dalam kegiatan pembelajaran di kelasnya masing-masing.

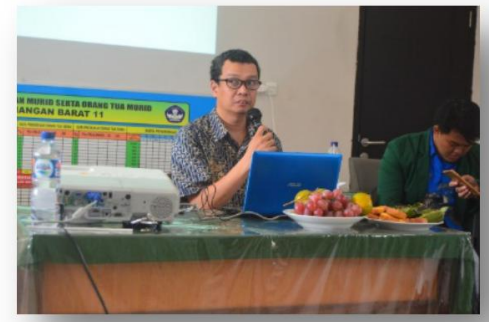

(a)

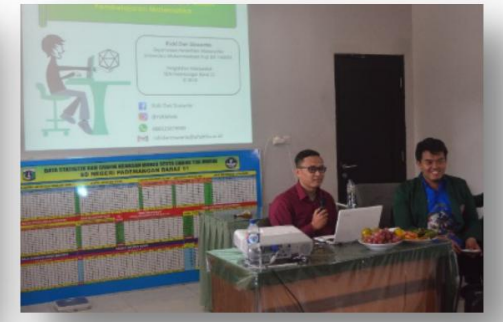

(b)

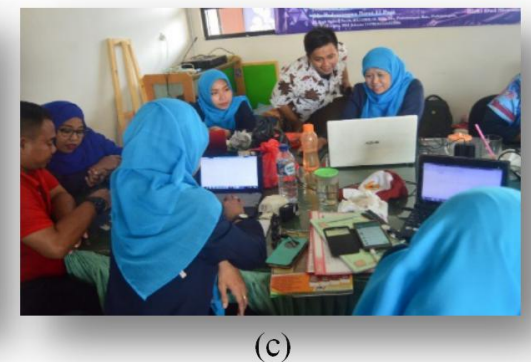

(c)

Gambar 1. (a) Materi 1 Penggunaan Media Pembelajaran di Sekolah Dasar, (b) Materi 2 Penggunaan Software GeoGebra, (c) Antusias peserta dalam penerapan software GeoGebra.

KESIMPULAN \& SARAN

Kegiatan yang telah direncanakan dan dilakukan oleh tim membuat beberapa perubahan pada mitra khususnya mitra kegiatan, diantaranya:

1. Peserta yang merupakan guru, semula tidak mengetahui software apa saja yang dapat 
digunakan dalam pembelajaran matematika di SD, kini tidak hanya sekedar tahu tetapi juga dapat mengimplementasikan software, terutama GeoGebra dalam pembelajaran.

2. Para guru sangat mengapresiasi kegiatan ini dikarenakan sangat mempermudah kegiatan pembelajaran matematika

Tim PKM menyadari masih banyak kekurangan dalam kegiatan ini, untuk itu disarankan, perlu adanya tindak lanjut secara berkala yang mengevaluasi perkembangan guru seperti diadakannya kelanjutan dari kegiatan ini agar guru lebih bisa dan lancar, khususnya dalam mengguanakan software di berbagai materi matematika. Penggunaan iptek untuk guru dapat membantu menyelesaikan soal-soal matematika dengan mudah dan guru dapat mengajar dengan lebih efektif.

\section{DAFTAR PUSTAKA}

Departemen Pendidikan dan Kebudayaan. (2013). Lampiran IV peraturan Menteri Pendidikan dan Kebudayaan Republik Indonesia nomor 54 tahun 2013 tentang Standar Kompetensi Lulusan: pedoman umum pembelajaran. Jakarta: Depdikbud.

Departemen Pendidikan dan Kebudayaan. (2013). Lampiran IV peraturan Menteri Pendidikan dan Kebudayaan Republik Indonesia nomor 65 tahun 2013 tentang Standar Proses. Jakarta : Depdikbud.

Departemen Pendidikan Nasional. (2006). Peraturan Menteri Pendidikan Nasional. 2006. Nomor 22 Tahun 2006 Tentang Standar Isi. Jakarta: Depdiknas

Djamarah, S. B \& Zain, A. (2006). Strategi Belajar Mengajar. Jakarta: Rineka Cipta.

Hohenwarter, M. \& Fuchs, K. (2004). Combination of Dynamic Geometry, Algebra, and Calculus in the Software System Geogebra. [Online]. Tersedia: www.geogebra.org/publications/pecs_200 4.pdf. [16 Nopember 2010].

Hohenwarter, M., et al. (2008). Teaching and Learning Calculus with Free Dynamic Matgematics Software GeoGebra. [Online]. Tersedia; http://www. publications.uni.lu/record/2718/files/ICM E11-TSG16.pdf.[15 Nopember 2010]

Kusumah, Y.S. (2003). Desain dan Pengembangan Bahan Ajar Matematika Interaktif Berbasiskan Teknologi Komputer. Makalah terdapat pada Seminar Proceeding National Seminar on Science and Math Education. Seminar diselenggarakan oleh FMIPA UPI Bandung bekerja sama dengan JICA.

Rifayanti, Z. E. T. (2017). Penggunaan Media Animasi Untuk Meningkatkan Hasil Belajar IPS Tentang Keanekaragaman Budaya Indonesia Siswa Kelas V SDN Cangkringsari Sukodono Sidoarjo. Publikasi Pendidikan, 7(2), 8994.

Sanjaya, W. (2009). Strategi Pembelajaran: Berorientasi Standar Proses Pendidikan. Jakarta: Prenada Media Grup.

Slameto. (2003). Belajar dan Faktor-faktor yang Mempengaruhinya. Jakarta: Rineka Cipta. 